\title{
Strategy: Does the Concept Exist in Islamic Sources of Knowledge?
}

\author{
Waseem Gul ${ }^{1}$ \\ ${ }^{1}$ MBA, MSc, Performance Manager (Technical Support), Ericsson Communication Co. Ltd., Beijing, P. R. China \\ Correspondence: Waseem Gul, MBA, MSc, Performance Manager (Technical Support), Ericsson \\ Communication Co. Ltd. Beijing, P. R. China. E-mail: waseem_gul2000@yahoo.com
}

Received: September 18, 2016

Accepted: September 28, 2016

Online Published: October 9, 2016

doi:10.5539/ibr.v9n11p146

URL: http://dx.doi.org/10.5539/ibr.v9n11p146

\begin{abstract}
The study brings new insights about the notion of strategy by exploring it in the Islamic sources of knowledge. It employs qualitative research methodologies to analyze the content taken from the texts of the Quran and the Hadith, their interpretations as well as from the biographies of Muhammad PBUH. It is part of the efforts which are being made to explore alternate perspectives in order to overcome the prevailing issues emerging in the classical management theory and practice. While works of scholars from cultural contexts different from the western cultures are surfacing in this area, it seems to be useful to also explore the Islamic sources of knowledge for the very purpose. Current study should be considered an early attempt in the specific area of strategy. It is a straightforward manner of looking into the Islamic sources of knowledge for the managerial wisdom and bringing it to light by an individual or collective effort. It should not be considered a way of negating the existing body of knowledge, but it is an attempt to bring something which may complement it.
\end{abstract}

Keywords: management, strategy, Islamic, knowledge, qualitative, migration

\section{Introduction}

\subsection{The Study and Its Objective}

Management theory and practice was developed and contributed largely by scholars and thinkers coming from the western cultural contexts. Lately, some contribution surfaced as a result of the work of scholars from non-western cultural contexts as well in order to cope with the challenges the classical management is facing due to changing economic and business environments.

'Strategy' is an extremely important aspect of management. Current study is aimed at exploring the concept of strategy in the Islamic sources of knowledge, i.e. the Quran and the Sunnah of Muhammad PBUH. A huge knowledge bank explaining multitude of aspects about Islam and its principles etc. is available with all the ease. However, the way it is presented to the world seems to be incompatible with the contemporary world of human thought and practice. But is it really incompatible in its essence? This is the question that has driven the need for current study. This is first of its kind as no previous literature of the similar sort could be found even after employing the best efforts. Being so, it contents itself to search, locate and establish if this very concept exists in the Islamic sources of knowledge? If so, then next steps could be to explore its epistemological orientation from an Islamic perspective, its similarities and differences with the same concept but coming from other cultural backgrounds and finally the possibility of its operationalization in the real-world management practices. To achieve this purpose, it tries to find the notions of strategy in the Quranic text, set its linguistic meanings and investigate how were the actions of Muhammad PBUH related to the notion in order to set contextual meaning for notions. Finally, it subjects the obtained set of notions to the Western concepts of strategy to see if these notions actually represent the same concept or it is something different. This is, in no way, an effort to negate or reject the existing literature on the subject, rather, it's part of the attempts to present another view to see if it could help in solving the issues which existing theory and practice is facing in the field of strategy.

\subsection{Significance of the Study}

During the last decade, Kazmi $(2003$; 2005) tried to set a research direction in order to explore management concepts from an Islamic perspective and investigate if they are workable? In his valuable works, he correctly gives an account of the contributions to this field made by scholars and thinkers from the cultural context rooted in the western world which he names Anglo-Saxon and Judeo-Christian cultural contexts. He also briefly introduces to the works which surfaced from cultural contexts other than the western such as Japanese (Ouchi, 
1981), Indian (Chakraborty, 1987; 1988; 1989), German (Stewart et al., 1994; Stewart, 1996) social heritages. This is, he considers, due to the fact that classical western approaches to management started appearing less or not invincible in socio-cultural and geo-economic contexts which are different from those in which the classical theory building and its practical implementation took place. He considers the current atmosphere a healthy one as the non-Western cultures have also started looking for alternate systems and the conventional management scholars seem to be open to accept alternate views, provided they are demonstrated as workable. Therefore, it is time now to avail the opportunity and focus on investigating into the paradigms of conventional management, and for comparing and contrasting them with what the Islamic approach to management has to offer. In this regard, he insists that the purpose of this effort should not be to criticize the conventional approach(s), but to offer new insights into what could possibly be wrong with it and how that wrong could be corrected. This may, in the long term, lead to a complementation rather than confrontation among the conventional and alternative approaches to management, including the Islamic approach, to address the universal concern for utilizing human ingenuity in order to manage organizations effectively.

Seeing the situation as encouraging on one hand, Kazmi (2003) expresses a sort of disappointment on the other hand while reviewing the work done as a result of effort of the Islamization of knowledge which took start during 1970 and reached its peak during 1980s and then 1990s producing some good knowledge in different areas but fainted after the year 2000 onwards. Management field is no different. Another issue is the lack of availability of purposeful qualitative work which could become a fountainhead of meaningful quantitative research. The available work is descriptive and not analytical thus does not propagate further research work. This is due to the fact that usually Muslim scholars consume their energies on proving that existing conventional theories or postulates are nothing new and that these were already there in the Islamic realm of knowledge. Such approaches may console Muslims, however, it poses a dangerous threat of diversion from what should actually be done. And it is very true that less attempts have been made to link the teachings of Islam to the modern management practices including strategy employing analytical tools and techniques. To fill this gap, Kazmi encourages the management researchers to explore the field of management from an Islamic perspective and provides them with an extensive and comprehensive proposal for research comprising four streams, i.e., "dig the gold approach", "chinks in the armor approach", "chinks in the armor approach", "delve deeper approach".

This proposal can be considered as an important milestone towards viewing the management concepts from an Islamic perspective as it insists on a wider and deeper theoretical and empirical study on which he himself has embarked on (Kazmi and Ahmed, 2006). This is something quite different from existing practices prevailing among Muslim scholarship as already mentioned.

Recently, Zandi et al. (2015) responded to this need and proposed an extensive empirical research plan which is aimed at finding the strategies of Muhammad PBUH that he adopted during his lifetime, especially those adopted during wars or battles, to see how they are being employed in current day business as well the outcome of the implementation of these strategies. This research is intended to be conducted in selected organizations in Malaysia. It seems to be an important step towards research in this area from an Islamic perspective, however, it would be valuable if an effort is made to first identify the concept of 'Strategy' within the Islamic sources of knowledge, comprehend it within the Islamic world-view, make comparisons with the same concept available in other world-views and then proceed for further theoretical and empirical research. Such study does not seem to exist after best effort was employed to search for that. Current study, thus, is an attempt to fill this gap while adopting one of the four approaches proposed by Kazmi (2003), i.e., the "dig the gold approach". This approach means a straightforward manner of looking into the Islamic sources of knowledge for nuggets of wisdom to be brought to light through individual or collective effort and is taken up by current study. Other three approaches are not touched here. This study, together with other studies, is expected to help avoid the same wrong which Muslim scholars have been committing of superficially announcing different the terminologies and concepts without going deeper into the world-view these come from and their implications in the philosophical and practical world.

\subsection{Scope of the Study}

The study focuses to explore the notion of strategy in the Islamic sources of knowledge following the "dig the gold approach". This approach means a straightforward manner of looking into the Islamic sources of knowledge for nuggets of wisdom to be brought to light through individual or collective effort. Therefore, current study will keep itself contented with this very purpose. Other three approaches, i.e., "chinks in the armor approach", "delve deeper approach" and the "hands-on approach" are not touched here in this study.

It embarks on literature review of the prevailing works on the subject of strategy from a western perspective in 
order to have a brief introduction to the body of knowledge that emerged over past several decades. This also helps to set certain set of concepts about the subject area which may be utilized when needed for utilization or comparisons. Then it embarks on a detailed exploration of the Islamic sources of knowledge, tries to find the evidences of the existence of the concept under discussion, analyzes and assesses these evidences, compares these with the notions obtained from the literature review. Then it makes conclusions, lists limitations and suggest for further research in the subject area. It ignores other perspectives for the sake of staying focused on the western perspective of strategy and incorporating it to understand the notion of strategy in the Islamic sources of knowledge.

\section{Literature Review}

\subsection{What Is Strategy}

We often hear the word strategy in connection with politics, defense, economics etc. and during past few decades within the business arena so much that if a simple search is made on the internet with the keyword 'Strategy', a pretty long list of books, journal articles, writers, consultancies appear showing that a huge field of research and practice exists in the name of strategy in general and in relation to business in particular. It seems that strategy is everywhere. But what is 'Strategy'?

It is of fundamental importance to understand the nature of strategy as the current study's sole focus is to explore the same themes within Islamic sources of knowledge. It would be impossible to do a valid search, making comparisons and reaching some results without deeply knowing this concept from the western perspective first. Several thinkers and authors have attempted to define the term strategy and its attributes in one way or the other. For this purpose, they have tried to answer the questions such as: What is strategy? Is it a plan? Does it refer to how to obtain the ends that are sought? Is it a position taken? Just as military forces might take the high ground prior to engaging the enemy, might a business take the position of low-cost provider? Or does strategy refer to the perspective, to the view one takes of matters, and to the purposes, directions, decisions and actions stemming from this view? Lastly, does strategy refer to a pattern in the decisions that are made and actions that are taken? For example, does repeatedly copying a competitor's new product offerings signal a "me too" strategy? Just what is strategy? Some of the important works answering such questions are as being presented here.

Urwick (1956) considers lack of strategy in an organization as no use of wisdom leads to disaster. Liddell Hart (1967) examines wars and battles from the time of the ancient Greeks through World War II and tried to define strategy as being a means to an outcome of the policy. Steiner (1979) noted that strategy entered the management literature as a way of referring to what one did to counter a competitor's actual or predicted moves. He also points out that there is little agreement on the meaning of strategy in the business world. Mintzberg (1994) concluded that people use 'Strategy' in four different ways, i.e., a plan, a pattern of actions, a position, a perspective and argued the emergent nature of strategy. Andrews (1980) presents it as the pattern of decisions that determines and reveals its objectives, purposes, or goals, produces the principal policies and plans for achieving those goals. Strategy guru Porter $(1980 ; 1996)$ explains strategy as being different and unique focusing on means and ends both. Tregoe and Zimmerman (1980) perceives strategy as the framework which guides those choices that determine the nature and direction of an organization. Robert (1993) argues that the real issues are strategic management and thinking strategically. Treacy and Wiersema $(1993 ; 1995)$ concludes that strategy is about keeping a focus on delivering certain value. Mintzberg et al. (1998) provide a lively account of ten 'Schools' of strategy thinking. De Wit and Meyer (1999) analyzes a series of key topics in the light of important articles that take diametrically opposed views for the sake of strategy synthesis. Yet, there are more specialized contrasts of perspective in the strategy field. Lowendahl and Revang (1998) provide a useful comparison of 'postmodern' approaches to strategy with 'Classical' 'modernist' approaches. Ghoshal et al. (1999) offer a passionate critique of the contemporary relevance of the 'Classical' approaches associated with Chandler and Porter. It can be argued that all these perspectives, while defining the term 'Strategy' and its attributes, do possess a validity in their claims considering the contexts in which these perspectives are being established.

Not long ago, Kazmi (2008) attempted to answer these question by putting forth the concept of strategy in a quite simple but comprehensive manner. He states:

"The term 'strategy' is derived from a Greek word strategos, which means generalship---the actual direction of military force, as distinct from the policy governing its deployment. Literally, therefore, the word 'strategy' means the art of the general. In business parlance, there is no definite meaning assigned to strategy. It is often used loosely to mean a number of things.

- A strategy could be a plan or course of action or a set of decision rules making a pattern or creating a common thread; 
- The pattern or common thread related to the organization's activities which are derived from the policies, objectives and goals;

- Related to pursuing those activities which move an organization from its current position to a desired future state;

- Concerned with the resources necessary for implementing a plan or following a course of action;

- Connected to the strategic positioning of a firm, making trade-offs between its different activities and creating a fit among these activities; and

- The planned or actual coordination of the firm's major goals and actions, in time and space that continuously co-align the firm with its environment.

In simplified terms, a strategy is the means to achieve objectives. In complex terms, it may possess all the characteristics mentioned above. With so many different interpretations of a term, it is really difficult to fathom what strategy really means. This is understandable. Yet we need to consider all these interpretations at once. This diversity of interpretations gives us valuable insights into what thinkers and writers have proposed from time to time. With the wealth of understanding we have at our command, thanks to the intellectuals who have contributed to creating it, we can broaden our thinking."

This brief account of the body of knowledge about the concept of strategy provides attributes attached to the concept of strategy.

\section{Methodology}

\subsection{Basic Terminology}

It might be useful to provide scholars, especially the non-Muslim ones, with some basic introduction to the themes and the terms used in this study:

- From an Islamic perspective, the divine revelation is the source of all knowledge (Azram, 2011). This revelation is the Quran (Al-Quran) which was revealed to Muhammad PBUH who, under the guidance of the God, practically modelled the principles of the Quran. This practical modelling of the Quranic principles by Muhammad PBUH is called the Way (the Sunnah). Thus the two primary sources of knowledge in Islam are the Quran and the Sunnah of Muhammad PBUH.

- Muslims use the word the God (Allah) for the creator, sustainer, omnipotent, omniscient etc.

- Quran is divided, based on different topics, into 114 Chapters (Surah) of unequal size where each chapter is comprised of multiple Verses (Ayat). The Sciences of Quran (Ulum al Quran) refers to the knowledge necessary for the interpretation, known as exegesis, of the words/verses in Quran.

- The reports about the statements, the acts or the silence about a matter by Muhammad PBUH are called the Hadith (Al-Hadith), narrated by his companions and transmitted through generations. Hadith, when studied by employing a specific technical knowledge called the Sciences of Hadith (Ulum al Hadith), provides information of the Sunnah of Muhammad PBUH.

- Muslims use PBUH (Peace Be Upon Him) for every prophet to show respect without any discrimination, hence they also do the same for Muhammad PBUH.

- Certain verses of the Quran and Hadith have been referred to in this study. In doing so, the format (Chapter: Verse: Word) for the Quranic verse while (Volume \#, Book \#, Hadith \#) for Hadith has been used.

- Makka is a city in the western part of Arab peninsula where Muhamad PBUH was born and initially tried to spread the message. Madina is another city in the north of Makka.

- Islamic resources of knowledge are fundamentally in Arabic language, however, utmost effort has been made to use the Arabic words to the least and Arabic transliteration has been provided where deemed necessary.

\subsection{Data Collection}

Documents have been used as sources of data since the nature of study is historical one. These documents include the Quran and the books of Hadith as primary data. Interpretations of these two, the biographies of Muhammad PBUH produced by renowned scholars and widely referred Arabic-English dictionary can be termed as secondary data. The term 'document' covers a very wide range of different documents entailing data available for assembling and analyzing. Bryman and Bell (2007) recommend the criteria of acceptable documents with the certain traits, i.e., can be read, has not been produced specifically for the purpose of research, is preserved to be 
available for analysis and is relevant to the concerns of the researchers in the business realm. It is argued, here, that Islamic sources of knowledge do qualify this.

Qualitative data includes locating the course of actions that Muhammad PBUH took during the event of migration from Makka to Madina from his biographies, locating verses in the Quranic text entailing specific words relevant to his thought and actions as well as their outcomes, referring to interpretations and dictionary in order to explore out the literal and contextual meaning of the relevant words and verses in order to ascribe some notional meanings to these.

\subsection{Methodology Used}

Due to conceptual nature of the study, an inductive approach for analysis is adopted. For this purpose, the methodology recommended by 'Grounded Theory' is employed. The purpose is to avoid as much pre-judgement or bias as possible, and to go in with an open mind to see what emerges/is grounded in the data alone, i.e., it has not been informed in any way by pre-existing hypothesis. The concept of 'Hermeneutics' was incorporated into this study which is content analysis technique with the aim of seeking the meanings of a text within social and historical context (Bryman and Bell, 2007). Complying with the requirements of the rules, a large scale study of Islamic sources was conducted and finally a specific event from the life of Muhammad PBUH was chosen for further deeper exploration to ensure the study stays within reasonable limits of length and breadth while trying to go into a good level of depth. Significant patterns of thought and action that appeared from the data exploration are noted down and conceptually codified to contemporary notions utilizing the literal and contextual meanings entailed by the observed patterns. It is notable that due to the descriptive nature of the data, only concepts can be derived from the emerging patterns and not necessarily the numbers. These concepts were subjected to verification from within the data sources for the sake of consistency and validity, i.e., to check if they really make some sense. Finally, the obtained concepts were compared to similar ones in the existing literature pertaining to strategy to arrive the conclusions. Apparently, this final comparison seems similar to 'Pattern Matching' approach but it turns out to be different if seen carefully as it doesn't make any presumptions or hypothesis before embarking on the study or analysis which are a necessary part of the pattern matching approach.

\section{Findings and Discussion}

\subsection{Purpose of Human Life and the Duties of Prophets}

Maududi (1988), in the introduction chapter of his vastly read interpretation of Quran, famous as 'Towards Understanding the Quran - Tafhim ul Quran', states the purpose of human life and duties of the prophets (messengers). Muhammad PBUH being the final prophet was revealed the Holy Quran with the following responsibilities assigned to him:

- Calling the people to the message of Allah, gathering the ones who accepted the message into a cohesive organization and training them with ethics set by the revelation.

- Engaging this organization to striving in order to establish a state based on the principles revealed by Allah to ensure a society enjoying a peaceful and prosperous life with internal peace and freedom from external threats.

- Thus enabling them to worship only one and the only Allah, in the individual as well collective spheres of life, in order to reap the fruits of the faith in this life and the life in the hereafter.

While trying to fulfill these duties Muhammad PBUH and his companions faced every type of opposition humans can think of in the form of oppression, execution and conspiracies of the pagans of Makkah (Known as Qu'raysh) as well as Jews and the opponents from within the ranks of Muslims (Known as hypocrites of Madina). This included abusing, physical and psychological torture, false propaganda, expulsion from homes and snatching of assets, execution and killing, waging wars, conspiring to kill Muhammad PBUH multiple times, conspiring to establish groups within larger Muslim society and many more. They went through such fierce challenge from beginning of the call in Makka to Taif and then in Madina till the time Makka fell to Muhammad PBUH during the last stage of his life. Moreover, there were challenges in human learning and development, cohesiveness of the Muslim organization, ensuring a peaceful and prosperous life for residents of the state of Madina after its establishment etc. As-Sallaabi (2005), Mubarakpuri (1996), Siddiqui (1998) have provided a good account of the problems and persecutions which Muhammad PBUH and his companions had to face.

\subsection{Migration to Madina}

Muhammad PBUH was always looking for people from alternate tribes and regions to spread his message so as 
to get strength and be able to establish a stronghold for his mission. Such efforts failed in regarding the city of Taif (A city near Makka), however, went successful for Madina. Some people from Madina who visited Makka to offer pilgrimage during the year 621 A.D. and Muhammad PBUH found the opportunity to meet them at 'Aqaba (A surrounding place of Makka) and presented to them the message of Allah. Next year, i.e., 622 A.D., more people from Madina met Muhammad at the occasion of pilgrimage, embraced Islam and the second pledge of the 'Aqabah took place. This provided Muhammad PBUH an opportunity what he was eagerly looking for. He ordered his followers to move to this new land, so they started moving to Madina sacrificing assets they possessed in Makka especially their homes and in some cases even their herds, jewels, slaves etc (Mubarakpuri, 1996); (Ibn Hisham, 2000)

"Apprehending the Prophet's migration to Madina, the Quraysh convened a high-level council attended by all the tribal chiefs at Dar al-Nadwah (Council House) to decide on a decisive course of action against the Prophet (peace be on him). They realized that once the Prophet (peace be on him) left Makka, he would be beyond their reach, rendering them helpless in face of a formidable threat. A group of them was of the view that the Prophet (peace be on him) should be imprisoned for life and kept in chains. This proposal was, however, turned down on the ground that the Prophet's detention would not deter his followers from preaching Islam and that they would seize the first opportunity to release the Prophet (peace be on him) even at the risk to their own lives. Another group suggested that the Prophet (peace be on him) should be exiled, for this would remove the mischief and subversion far from Makka, and it would not matter where he spent his days nor what he did, for Makka would be immune from his influence. This proposal, too, was discarded for fear of the Prophet's persuasiveness and eloquence, and his ability to win the hearts of the people of other tribes and thus pose a greater threat in the future. Finally, Abu Jahl suggested that a band of young men drawn from all the different clans of the Quraysh should jointly pounce upon the Prophet (peace be on him) and kill him. In such a case the responsibility for his blood would rest upon all the clans of the Quray'sh. It would thus become impossible for 'Abd Manaf, the Prophet's clan to take revenge on any one particular clan. Such a move would compel the Prophet's relatives to drop their claims for retaliation and force them to settle for blood-money. Accordingly, the young men charged with the execution of this plan were selected, and were advised of the exact place and time at which they were expected to carry out the crime. Not only that, the would-be assassins did indeed arrive at the appointed place at the appointed time. However, before they could harm him the Prophet (peace be on him) managed to escape safely. The Quraysh plot was thus frustrated at the eleventh hour."

The above passage, which gives a clear picture of the event, has been taken from Maududi's interpretation of the verse (8:30). Below are the translations of the same verse by Asad (1980) and Maududi (1994) respectively:

"AND [remember, O Prophet,] how those who were bent on denying the truth were scheming against thee, in order to restrain thee [from preaching], or to slay thee, or to drive thee away: thus have they [always] schemed: but God brought their scheming to nought - for God is above all schemers."

"And recall how those who disbelieved schemed against you to take you captive, or kill you, or drive you away. They schemed and Allah did also scheme. Allah is the best of those who scheme."

Few points need to be considered from this verse and its interpretation, i.e.:

- Quraysh schemed to assassinate Muhammad PBUH and also Allah schemed to save him

- Allah's scheme was successful and Muhammad PBUH moved from Makka to Madina safely

- Which means that Muhammad PBUH reached Madina safely which, in turn, means Allah's scheme was successful while Quraysh failed in their scheme which is exactly what's being referred to in the verse $(8: 30)$.

Questions may arise here such as if Muhammad PBUH migrated as result of a miracle, an outcome of a mere use of his intellect or he leveraged his intellect to the best possible levels under the divine guidance of Allah to accomplish this move?

There exists a lot of literature regarding these questions with competing reasoning. Muhammad PBUH has been portrayed by many as a traditional religious figure blessed or equipped with certain super natural powers or miracles and the responsibilities he was assigned by Allah got accomplished merely benefiting from those miracles. Another group went the other extreme and denied the very existence of miracles while stressing the utilization of the intellect only. Yet another group of scholars tried to bring a balanced among these extreme views by trying to explain miracles utilizing scientific explanation of the miracles in addition to the as use of the intellect. Guessoum (2011) has discussed different views of these schools of thoughts and presented his critique as well. Instead of indulging into detailed philosophical debate about such issues, this study contents itself with the practical aspect of the life of Muhammad PBUH and adopts the view presented by Siddiqui (1998) that Muhammad PBUH was a human being assigned with the prophetic responsibilities. Prophets always receive 
guidance from Allah but act using their intellect under this revealed guidance. Same was the case of Muhammad PBUH. It is important to note that in the case of Muhammad PBUH, Allah didn't eliminate His opponents by Himself or blessed Muhammad PBUH with a throne to rule his nation. Rather, He got it accomplished on the hands of Muhammad PBUH via a visible struggle entailing human observation, analysis, assessing, planning, acting and controlling under His continuous guidance and help. It clearly indicates the importance of the human intellect and Muhammad PBUH being the founder of a new era of human civilization in terms of unlocking the human intellect to its maximum possible potentials.

Allah revealed to Muhammad PBUH, as and when needed, to guide him and his companions (organization) in order to enable them to stick to their belief firmly, keep their morale high, never give up the hopes and stay informed and warned about the efforts their opponents were engaged in. Since Muhammad PBUH was the last of the messengers, therefore, it was necessary that this revelation contains principles about anything possible in human life during the life of Muhammad PBUH till the end of the world. These principles were practically modelled by Muhammad PBUH. Therefore, the scheme of Allah in the verse (8:30) points to the scheme which Muhammad PBUH devised under the revealed guidance. Thus it can be deduced that:

1- Opponents of Muhammad PBUH are in fact the opponents of Allah

2- Schemes of Allah are the schemes of Muhammad PBUH

3- Schemes of opponents of Muhammad PBUH are schemes of opponents of Allah

4- Hence any scheme of opponents against Muhammad PBUH is actually a scheme against Allah

5- Schemes of opponents failed while schemes of Muhammad PBUH succeeded means schemes of Allah succeeded

In a diagrammatic form it may be presented as follows:

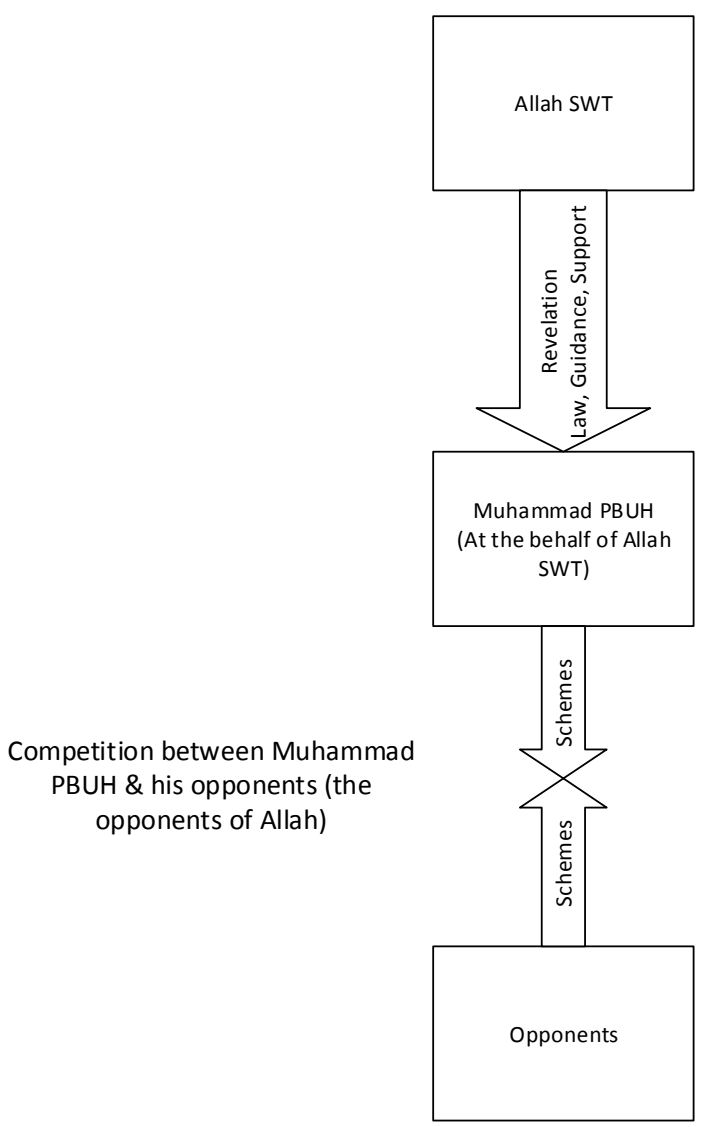

Figure 1. Competition between Muhammad PBUH \& his opponents (Opponents of Allah)

To further this discussion, it is important to go through the highlights of the event to which the verse (8:30) refers to, i.e., the migration of Muhammad PBUH to Madina and carefully see the scheme Muhammad PBUH devised and try to learn, if anything, related to current study. This took place when Allah permitted Muhammad PBUH and also informed him via the angel Gabriel. Leveraging the works of Lings (1983), Mubarakpuri (1996), 
Siddiqui (1998), Ibn Hisham (2000), following key points can be drawn about the whole event:

- To achieve this objective, the leader counselled with his close companions and devised a plan to make a secure move for the whole organization to a safe place, i.e., Madina.

- Based on internal and external environment analysis, a best possible secure plan of migration was chalked out and executed keeping in view the strengths, weaknesses, opportunities and threats for different segments of the organization.

- The leader showed steadfastness and calmness avoiding any panic. It displayed its care for the followers by staying in Makka and looking after the migration till a vast majority of the members of the organization moved successfully to Madina and tried to help those who failed due to lack of resources or were held by the Quraysh for one reason or the other.

- Highest level of secrecy was observed about the moves of the leadership from the time of planning of this move, through the pathway to Madina till getting out of the reach of the Quraysh. At the same time, leadership outwitted Quraysh by invoking a scheme of intelligence which helped it beware of each and every move of the opponents.

- Leaders capabilities in the arena of human resource development had produced a highest degree of loyalty among the followers to the leadership for the cause of the organization. In order to keep the opponents confused about leader's movement, a loyal follower sacrificed his life by sleeping in the bed of Muhammad PBUH.

- Perfect selection of time to start the move keeping the opponents unaware, movement towards the direction least expected by the enemy and best possible positioning by selecting the adequate and quickly reachable hideout to ensure safety, fetching information about enemy's moves via intelligence and receiving food supplies at the early stages of the travel.

-Well trained followers not only sacrificing but also utilizing wisdom to utilize camouflaged in erasing any possible sign of the leader's presence in the hideout.

- Through best resource allocation for the provisions of life commodities for the travel, logistics availability in time, choosing best consultancy to mark the safest and fastest pathways to the destination was ensured. Keeping least number of followers during travel for faster and lighter move and maneuver. Backup plans were there as much as possible.

- Staying intact with the principles of nobility and piety and not inflicting unnecessary compulsions on followers.

- Even after such remarkable diligent scheming and its execution, complete reliance on Allah's help, and it came to him in reality, in reaching Madina and achieving the objective.

Recalling the concept of strategy in the western cultural realm:

- A strategy could be a plan or course of action or a set of decision rules making a pattern or creating a common thread;

- The pattern or common thread related to the organization's activities which are derived from the policies, objectives and goals;

- Related to pursuing those activities which move an organization from its current position to a desired future state;

- Concerned with the resources necessary for implementing a plan or following a course of action;

- Connected to the strategic positioning of a firm, making trade-offs between its different activities and creating a fit among these activities; and

- The planned or actual coordination of the firm's major goals and actions, in time and space that continuously co-align the firm with its environment."

It can safely be said that Muhammad PBUH took the decision to migrate to Madina, devised a plan with a detailed course of actions from start to end, complied to certain rules by environment analysis. His decisions and plans created a pattern of movement of his organization (companions) as deemed feasible to achieve a favorable position by reaching, gathering and establishing a state enabling them to be strong enough to achieve their higher order objective of worshiping to Allah. Action plan was executed with diligence and perfect resource configuration. Muhammad PBUH and his organization had to accept the tradeoffs in terms of leaving their 
beloved city, society, assets etc and moving to a completely new environment for the sake of higher order objective in a manner that each and every action of the plan was completely aligned with each other and with the mentioned objectives. Muhammad PBUH's whole scheme or plan and its execution during the realization of Allah's scheme (Being the messenger's scheme in this material world) can be clearly said to qualify the definitions of strategy in the western realm.

But the discussion doesn't end here...!

It's interesting and important to look further into the verse (8:30) and explore it a bit more in a wider context of the Quran to see if it really supports the conclusion current study just made?

The word 'scheme' occurs four times in both the translations which is translation of the words derived from the trilateral root mim $k \bar{a} f r \bar{a}($ (2). There occur 43 words in different forms derived from the same root in Quran at different places.

(3:54:1), (3:54:2), (6:123:8), (6:123:11), (6:124:29), (7:123:12), (8:30:2), (8:30:11), (8:30:12), (10:21:22), (12:102:14), (13:42:2), (14:46:2), (16:26:2), (16:45:3), (16:127:14), (27:50:1), (27:50:3), (27:70:9), (35:10:16), (40:45:5), (71:22:1), (7:99:2), (7:99:6), (7:123:11), (10:21:11), (10:21:17), (12:31:3), (13:33:29), (13:42:7), (14:46:3), (14:46:6), (14:46:9), (27:50:2), (27:50:4), (27:51:5), (34:33:7), (35:10:21), (35:43:4), (35:43:8), (71:22:2), (3:54:6), (8:30:16)

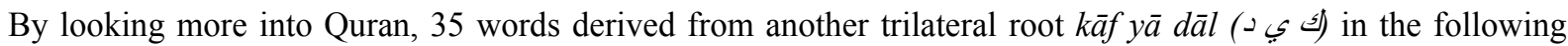
verses:

(7:195:24), (11:55:3), (12:5:8), (12:76:12), (21:57:2), (77:39:5), (86:15:2), (86:16:1), (3:120:15), (4:76:17), (7:183:4), (8:18:5), (12:5:10), (12:28:10), (12:28:12), (12:33:12), (12:34:6), (12:50:21), (12:52:11), (20:60:4), (20:64:2), (20:69:10), (21:70:3), (22:15:20), (37:98:3), (40:25:15), (40:37:19), (52:42:3), (52:46:5), (68:45:4), (77:39:4), (86:15:3), (86:16:2), (105:2:3), (52:42:7)

Yet 5 more words derived from another trilateral root $k h \bar{a}$ dăl 'ayn $(\varepsilon\lrcorner \dot{\mathcal{C}})$ are found in the following verses:

(2:9:6), (8:62:4), (2:9:1), (4:142:3), (4:142:6)

A careful check in both the translations, it was found that Asad and Maududi have translated these words as:

scheme; plot; devise; contrive; try to outwit; guile; artful scheme; artifice; sought to do evil; artful; trap; deceive; strategy; stratagem

It is established fact that these words fall in the verses when Allah talks about the plans of the opponents of the messengers. At some occasions, Allah clearly mentions his supremacy over the entire being and capability to turn around these kind of plans. Moreover, Allah uses these verses as a source to continuously inform, warn, console Muhammad PBUH and his followers so as to assure them His complete and perfect help, provided they follow the revelation.

It must be noted that literal and contextual meanings of words and verses of the Quran need to be interpreted by carefully employing specific knowledge known as The Sciences of Quran (Denffer, 1994). This study has leveraged the works of Asad (1980) and Maududi (1988) to understand the meanings of these words since both have rich technical knowledge and have the proven ability of clarity in explanations and choosing the words and phrases which let the reader not deviate from the core message of the Quran. Moreover, the meanings of these words and their derivatives were verified to be available in Arabic-English Lexicon by Lane (1863) to solidify the fact that the meanings they used are not far-fetched.

Moreover, the Hadith literature has been explored to see if any of these words or something similar exist in it pertaining to the subject under consideration in the Sunnah of Muhammad PBUH and how was it understood by the scholars?

Sahih al Bukhari being the most authentic book of Hadith is selected which entails the saying of Muhammad PBUH which is:

'War is deceit.' (Volume 4, Book 56, Hadith \#3028, 3029, 3030)

Renowned scholar Khan (1997) used the word 'Deceit' to translate the actual Arabic word which comes from the trilateral root $k h \bar{a}$ dăl 'ayn ( $(\dot{\varepsilon} \dot{\mathcal{C}})$ in Arabic. An-Nawawi (2012) interpreted this saying of Muahmmad PBUH as:

'employing a strategy which causes misunderstanding to the enemy, and one's real intent does not become evident to them. This is permissible in Islam in the state of war.'

While al-Khattab (2007) uses the word 'stratagem' for the same Arabic word which falls in a similar Hadith but 
narrated by another companion in another highly authentic book of Hadith Sahih Muslim (Vol. 5, Book 32, Hadith\#20).

\subsection{Final Comments}

From the overall meanings of these words and their use in the context of the events as interpreted by these the scholars and adding up the meanings of the Hadith, it is evident that the notions attributed to these words are similar to the attributes of the concept of the strategy as already discussed above. This further solidifies the conclusion made earlier that the schemes of Muhammad PBUH under the guidance of Allah can be termed as 'Strategy'.

\section{Conclusions, Limitations and Future Research}

- Current study has tried to lay down a foundation towards large scale research by providing evidence that the concept of strategy is not something alien to Islam and can be traced into the primary sources of knowledge, i.e., the Quran and the Sunnah of Muhammad PBUH. This study proves its existence in relation to the event of emigration travel of Muhammad PBUH.

- While this study explored one event from the life of Muhammad PBUH, there is a possibility to look into other events of his life for the same purpose and others as well.

- It doesn't concern with the philosophical or epistemological aspects of the concept from an Islamic perspective or any other perspective. This is intended to be the next venture after the current one.

- It doesn't look into the differences (similarities) between the world-views of the scholars from Anglo-Saxon and Jeudo-Christian cultural background and that of Islamic world-view. This study doesn't bother Far-eastern notions about strategy for comparison nor does it touches those coming for Indian-Hindu cultural background. This could also be a part of a separate research.

- Operationalization of the concept of strategy in the contemporary business and management is yet to be explored from an Islamic perspective. The outcomes of such an exploration are expected to present a clear view if the concept is worth considering or workable?

\section{References}

Al-Bukhari, M. (1997). Sahih al Bukhari Vol (4). Trans. Khan, M. M., Riyadh: DARUSSALLAM Publishers and Distributors.

Andrews, K. (1980). The Concept of corporate strategy 2nd Edition. Homewood, IL: Dow-Jones Irwin.

An-Nawawi, I. A. Z. (2012). Riyadh us saleheen: Arabic - English [Online] Retrieved on 7th September, 2016, from http://www.islamicbulletin.org/free_downloads/resources/ryad_salehen_new.pdf

Asad, M. (1980). The message of Quran. Gibraltar: Dar al-Andalus Limited.

As-Sallaabi, A. M. (2005). Noble life of the Prophet Vol (1). Riyadh: Dar-us-Salam Publications.

Azram, M. (2011). Epistemology - An Islamic Perspective. IIUM Engineering Journal, 12(5), 179-187.

Bryman, A., \& Bell, E. (2007). Business research methods. 2nd Edition. Oxford: Oxford University Press

Chakraborty, S. A. (1987). Managerial effectiveness and quality of work life: Indian Insights. New Delhi, Tata McGraw-Hill.

Chakraborty, S. A. (1988). Foundations of managerial work: Contributions from Indian thought. Bombay: Himalaya Publishing House.

Chakraborty, S. A. (1989). Achieving managerial excellence: Insights from Indian organizations. New Delhi: Macmillan.

De Wit, B., \& Meyer, R. (1999). Strategy synthesis. London: Thomson.

Denffer, A. V. (1994). Ulum al Quran: An introduction to the sciences of the Qur'ān. Leicester: The Islamic Foundation.

Ghoshal, S., Bartlett, C., \& Moran, P. (1999). A new manifesto for management. Sloan Management Review, Spring, 9-20.

GUESSOUM, N. (2011). Islam's quantum question reconciling muslim tradition and modern science. New York: I.B.Tauris and Co Ltd.

Ibn al-Hajjaj, I. A. M. (2007). Sahih Muslim Vol (4) Tran. Al-Khattab, N., Riyadh: DARUSSALLAM Publishers and Distributors.

Ibn, H. (2000). Seerat Ibn Hisham. [Online] Retrieved on 7th September, 2016, from 
http://www.kalamullah.com/Books/Sirat\%20Ibn\%20Hisham.pdf

Kazmi, A. (2003). Proposed research agenda in Islamic perspectives on management studies. IIUM Journal of Economics and Management, 11(2), 197-227.

Kazmi, A. (2005). Probable differences among the paradigms governing conventional and Islamic approaches to management. Int. J. Management Concepts and Philosophy, 1(4), 263-289. http://dx.doi.org/10.1504/IJMCP.2005.008529

Kazmi, A. (2008). Strategic management \& business policy. New Delhi: Tata McGraw-Hill Publishing Company Limited.

Kazmi, A., \& Ahmad, K. (2006). Management from Islamic perspective. Kuala Lumpur: International Islamic University of Malaysia Press.

Lane, E. W. (1863). Arabic-English Lexicon. [Online] Retrieved on $6^{\text {th }}$ September from http://www.tyndalearchive.com/tabs/lane/

Liddell, H. B. H. (1967). Strategy. New York: Praeger.

Lings, M. (1991). Muhammad: his life based on the earliest sources. CAMBRIDGE: THE ISLAMIC TEXT SOCIETY.

Lowendahl, B., \& Revang, O. (1998). Challenges to existing strategy theory in a post-industrial society. Strategic $\begin{array}{llll}\text { Management } & \text { Journal, } & \text { 755-774. }\end{array}$ http://dx.doi.org/10.1002/(SICI)1097-0266(199808)19:8<755::AID-SMJ968>3.0.CO;2-A

Maududi, S. A. (1988). Towards understanding Quran Vol (I to XI). Trans. \& Ed. Ansari, Z.I. Leicester: The Islamic Foundation.

Mintzberg, H. (1994). The rise and fall of strategic planning. New York: Free Press.

Mintzberg, H., Ahlstrand, B., \& Lampel, J. (1998). Strategy safari: A guided tour through the wilds of strategic management. London: Prentice Hall.

Mubarakpuri, S. R. (1996). Ar-raheequl mukhtum (The Sealed Nectar). Riyadh: Dar-us-Salam Publications.

Ouchi, W. G. (1981). Theory Z. New York. New York: Addison-Wesley.

Porter, M. E. (1980). Competitive strategy. New York: Free Press.

Porter, M. E. (1996). What Is Strategy? Harvard Business Review, 74(6), 61-78.

Robert, M. (1993). Strategy: Pure and simple: How Winning CEOs Outthink Their Competition. New York: McGraw-Hill, Inc.

Siddiqui, N. (1998). Mohsin e insaniyat 28th Edition. Lahore: Al-Faisal Publishers and Distributors.

Steiner, G. (1979). Strategic planning. New York: Free Press Paper Back.

Stewart, R. (1996). German management: a challenge to Anglo-American managerial Assumptions. Business Horizons, May-June, 52-54. http://dx.doi.org/10.1016/S0007-6813(96)90008-7

Stewart, R., Barsoux, J., Kieser, A., Ganter, H., \& Walgenbach, P. (1994). Managing in Britain and Germany. London: Macmillan Press. http://dx.doi.org/10.1007/978-1-349-23584-1

Treacy, M., \& Wiersema, F. (1993). Customer Intimacy and Other Value Disciplines. Harvard Business Review 71(1), 84-93.

Treacy, M., \& Wiersema, F. (1995). The discipline of market leaders. Reading, MA: Addison-Wesley.

Tregoe, B., \& Zimmerman, J (1980). Top management strategy: WHAT IT IS \& HOW TO MAKE IT WORK. New York: Simon and Schuster.

Urwick, L. (1956). The Manager's Span of Control. Harvard Business Review, 34, 39-47.

Zandi, G. R., Joupari, N. Z. P., \& Aslam, A. (2015). The Strategies in the battles and Struggles of Muhammad: How It Can Be Applied in Modern Business. International Business Research, 8(11), 84-110. http://dx.doi.org/10.5539/ibr.v8n11p84

\section{Copyrights}

Copyright for this article is retained by the author(s), with first publication rights granted to the journal.

This is an open-access article distributed under the terms and conditions of the Creative Commons Attribution license (http://creativecommons.org/licenses/by/4.0/). 